\title{
Ивица Чаировић
}

Православни богословски факултет

Универзитет у Београду

e.mail: icairovic@bfspc.bg.ac.rs

\section{СТАТУС ХИНКМАРА ИЗ РЕМСА (806-882) НА ДВОРУ КАРЛОВИХ НАСЛЕДНИКА И У ФРАНАЧКОЈ ЦРКВИ. БИОГРАФСКЕ ЦРТИЦЕ И БОГОСЛОВСКИ ДОПРИНОС}

\begin{abstract}
Anстракт: Овај рад ће - кроз анализу биографских иртица из живота Хинкмара из Ремса (806-882) - понудити неколико равни приликом анализе историјскобогословских тема из 9. века. На првом месту биће анализиран однос наследника Карла Великог међу собом и са свим релевантним факторима на Западу у истом периоду, затим ће богословске теме бити сагледане кроз призму дела Хинкмара из Ремса, са посебним освртом на однос са римским епископом и на развој римског примата на Западу у средњем веку. Поред историјских догађаја Хинкмар је живо учествовао у ирквеном животу у Франачкој империји кроз саборско деловање, писање списа̂ и утииајем на нижи клир, тако да ће богословско-канонска анализа Хинкмаровог деловања очитати духовно стање на франачком двору и у селима и градовима, као и однос Рима и Ахена у контексту јурисдикиије на Западу Европе у 9. веку. Закључак овог истраживања треба да помогне у сагледаваюу односа Рима и Франачке државе у том периоду, али и развоја германског менталитета у хришћанском етосу Западне Европе у средњем веку.

Кључне речи: Хинкмар из Ремса, Карло Велики, Лудвиг Побожни, Лотар, Карло Ћелави, Карломан II, папа Никола I, монах Готшалк
\end{abstract}

Увод

Јачање Франачке државе на Западу Европе у средњем веку условило је велике верско-политичке промене, а Ахен је постао средиште владара који је желео да уздигне своју државу и омогући да преузме место Рима на Западу. Царев двор је постао средиште новог погледа на државу и Цркву, појавила се нова енергија и снага која се испољавала у ставовима Карла Великог да треба окупити све интелектуалце тог времена на једном месту, у Ахену, како би покренули свеопшту ренесансу на свим просторима Франачке државе. Заједнички циљ Алкуина, Петра Граматика, Павла Ђакона, Павлина из Аквилеје, Рада, игумана Фулрада, и осталих, створили су услове за каролиншку ренесансу. Сви ови интелектуалци и ерудите тог времена носили су карактеристике свог поднебља, своје отаџбине (Енглеска, Италија, германски део Франачке) и хришћанске вредности, тако да су свој рад могли комплементарно да представе тадашњем западном свету.

Студија почива на истраживањима Жана Девизеа и Рејчел Стоун, која су комплементарна и синтетишу све напоре ранијих историчара, али уз анализу историјских 
извора који су били доступни у оквиру едиције MGH и који доводе до закључака о Хинкмару из Ремса као личности која обележила 9. века у Франачкој држави. ${ }^{1}$

\section{Историјски контекст Хинкмарове младости. Прва половина 9. века}

Девети век карактеришу велике промене у Западној Европи, јер се почетком овог века франачка територија брзо шири, Карло Велики заузима средишње место у политичком животу Западне Европе, али је после његове смрти и многих перипетија територија увећане Франачке империје подељена између његових наследника; са друге стране, Ахен - као престоница Франачке државе - преузима прерогативе средишта једног народа и новог менталитета у свим аспектима, а посебно у интелектуалнокултуролошком и верском, те ова нова империја на европском Западу израста у врло моћног чувара традиционалних вредности римске државе и Цркве. Сарадња Рима и Ахена огледа се у делима насталим у том периоду, затим у преписци коју су водили папа и франачки владари и црквени великодостојници, и - на крају - у компатабилним одлукама франачких сабора из тог периода са римском канонском праксом.

За Хинкмара се не зна са сигурношћу где и када је рођен, али се углавном каже да је рођен између 802-810. године у племићкој породици Западних Франака у северном делу Франачке државе. ${ }^{2}$ Младост је провео у манастиру Светог Дионисија под патронатом Хилдуина који је 822. године постао дворски капелан, и који се бринуо о свим ахенским клирицима. Заједно са собом у Ахен на двор Лудвига Побожног повео и младог Хинкмара, где се он одмах суочио са основама и методологијом политичке и црквене администрације у новонасталим околностима после смрти цара, када је требало сачувати огромну државу у границама које је утврдио Карло Велики. После његове смрти дошло је до наглог распада каролиншке државе. Карлови наследници нису били у стању да одрже континуитет царства и територијални интегритет, јер су околни феудалци ојачали и почели да разарају компактност Франачке државе. На Хинкмара у трећој деценији 8. века у Ахену утиче рођак Карла Великог, Адалард који је умро 826. године у том дворском амбијенту где је Лудвиг разним покајним церемонијалима желео да се искупи за личне грехе. У том периоду на двору се развија и владарска германска идеологија, која је подразумевала уску сарадњу владара, епископа и народа; дакле, државе и Цркве. ${ }^{3}$

После смрти Карла Великог царску позицију преузео је његов син Лудвиг Побожни, чија владавина није наставила очевим путем, јер је његова власт обележена порастом моћи свештенства и борбе око престола. Лудвиг је папи потврдио сва права Римске Цркве, а папство је изузео из царске јурисдикције па је због таквог односа према Цркви, назван Побожним. Прогласио је за свог савладара свог најстаријег сина Лотара. Касније је добио још једног сина, Карла Ћелавог, са другом женом, која је престо хтела да осигура свом сину, па је таква ситуација изазвала низ грађанских ратова после смрти Лудвига Побожног.

1 Monumenta Germaniae Historica https://www.dmgh.de, посећено 2. јануара 2021.

2 Schrörs 1884, 9-10, 25; Devisse 1976, 1096-7; Böhringer 1992, 1-2.

3 Свака друштвена класа (ordo) имала је свој ministerium (клирикална служба или дужност), који је био налик владарском ministerium који је водио рачуна и бринуо и за послове државе и Цркве. Епископи су у овом систему себе видели као неко ко не дели моћ са владаром, већ и одговорност чак и већу од цара, пошто су сви одговорни Богу за све своје грехе и за грехе свог народа, али и владара и владарске породице. Ова теорија је свој врхунац досегла на црквеном сабору у Паризу 829. године. Види Patzold 2008, 105-84. 
Лудвиг Побожни 829. године, Хинмара одређује за помоћника Хилдуину како би увео и усталио бенедиктинско правило у манастиру Светог Дионисија. ${ }^{4}$ Тако је младић у периоду 829-840. године, иако је свој живот посветио монаштву, ипак радио између двора и манастира.

Тачније, Лудвигу се 823. године родио син Карло Ћелави коме је 829 . године отац преписао територије: Алеманију, Алзас, Рецију и део Бургундије, које су биле намењене старијем Лудвиговом сину, Лотару који ће га, у савезу са осталим старијим Лудвиговим синовима, приморати да 830. године поништи претходну одлуку. Фактичку власт преузима Лотар, а Лудвиг - у тој ситуацији - живи као заробљеник. Исте године двојица Лудвигових синова - Пипин Аквитински и Лотар - удружено нападају оца, али он наставља да влада на целој територији царства. Синове је у побуни против цара подржао и Хилдуин, кога је Лудвиг 831. године протерао у Саксонију. Како је сам говорио, Хинкмар је био човек од поверења Лудвига Побожног у периоду од осам година, али не у континуитету, већ најмање из два пута, ${ }^{5}$ иако то није поткрепљено другим историјским изворима. Хинкмар, ипак, не пише папи Николи о томе да су Лудвигови синови - Лотар, Пипин и Лудвиг Немачки - напали оца 833/34. године. ${ }^{6}$ Флодоард наводи да је Хинкмар био задужен за чување светих мошти у манастиру Св. Дионисија (custos sacrorum pignerum), а сигурно је учествовао у писању списа Miracula sancti Dionysii и ширењу култа Св. Дионисија у свим франачким областима пре Лудвигове смрти 840. године. ${ }^{7}$ Између 829. и 832. године, Хинкмар се вратио у манастир Св. Дионисија, али ипак није јасно каква је била његова улога у реформисању манастирског живота. Почетком 835. године војска је Лотара присилила да напусти Ахен и врати се у Италију, а Лудвиг је поново враћен на ахенски престо. Знатно повећање Карловог поседа довело је до сукоба са Лудвигом Немачким и до нове поделе царства, а после смрти Пипина Аквитанског дошло је и до седме по реду поделе Карлове империје. Лудвиг је извршио осму поделу 839. године, поделивши царство између Лотара и Карла. После Лудвигове смрти (840), ${ }^{8}$ Хинкмар је подржао Карла Ћелавог, ${ }^{9}$ можда зато што је он на управу добио северозападне делове Франачке империје, односно Хинкмарову домовину. На неки начин, Хинкмар је најбоље разумео потребе становништва Западне Франачке, после свих побуна и подела у царству.

4 Флодоард је навео ову епизоду из Хинмарове ране младости јер је нашао те податке у архиви у Ремсу, уз то напомињући да је био врло духован и да је делатно живео свој монашки живот.

5 PL 125, Juramentum quod Hincmarus Archiepiscopus edere jussus est apud Pontigonem. col. 1128: pater vester ... qui mihi per octo circiter annos secreta sua indubitanter credidit.

6 Epistola 198, 1990, 210.

7 Flodoard 1854, 191.

8 Лудвиг Побожни умире 20. јуна 840. године, а одмах затим међу његовим синовима избија нови грађански рат, који ће бити решен Верденским споразумом (843) и деобом Карловог царства на три дела, који постају језгра будућих држава: Француске, Немачке и Италије.

9 Родио се кад су његова браћа већ одрасла и већ су владали неким областима. Његов отац Лудвиг I Побожни се нашао у проблемима, како да одузме већ додељену земљу својим старијим синовима, и додели једну област Карлу Ћелавом на управу. Најпре је покушао да му додели Алеманију, па онда Италију, 832. године, и то после Лотарове побуне, те на крају и Аквитанију. Бројне побуне и мирења Лудвига I Побожног са Лотаром и Лудвигом I Немачким час су доприносили да Карло Ћелави има своје поседе, а час да остаје без њих. Ипак Лудвиг I Побожни се није предавао и успео је да издејствује код старијих синова да Карлу Ћелавом буде додељена цела Француска на управу. Када je Луј I Побожни обавезао великаше и племство у Западној Франачкој, 837. године, да прихвате Карла Ћелавог за владара, као његовог наследника, синови су се поново побунили. Пипин Аквитански је умро 838. године, па је Карло Ћелави напокон добио западни део Каролиншког царства на управу. 
Исте године, Лудвиг Немачки и Карло су се удружили против Лотара. Приморали су га да се повуче у Италију, а поседе су поделили међу собом (девета подела извршена 842. године). Током овог међудинастичког сукоба Хинкамарова улога остала је нејасна, јер ни они историјски извор који описују овај братоубилачки рат не спомињу Хинкмара, али се може наслутити да је он остао лојалан Карлу, који му је између 840 . и 845. године дао на управу (regimen) један или више манастира (Нотр Дам у Компињу и Светог Германа близу Бовуа). ${ }^{10}$ Све жешћи напади Нормана довели су - ипак - до измирења браће и коначне поделе која је августа 843. године извршена у Вердену. У складу са Верденским споразумом, Лотару је, сем Италије, дато и уско подручје око Провансе. Карлу су припале земље на западу, а Лудвигу на истоку.

У предверденском периоду (840-843), догодила се врло битна ствар у архиепископији Ремса која се односила на касније време, када је Хинкмар био архиепископ у том граду. Шта се десило? Док је у току рата Лотар држао те области, вратио је на архиепископску катедру Ебоа, ранијег архиепископа, који је то искористио и рукоположио у кратком периоду много клирика, који ће у каснијим данима правити проблеме Хинкмару. Са друге стране, област архиепископије у Ремсу се после географске поделе услед договора у Вердену (843) налазила на граници између Лотара (један део и цела архиепископија камбријска - Archdiocesis Cameracensis, где је пре тога архиепископ био Халитгар (817-831), црквени писац и проповедник (мисионар) међу Данцима) и Карла (већа територија се налазила у Западној Франачкој под Карловом управом). ${ }^{11}$ Ова архиепископија имала је своју земљу и на територији Источне Франачке, којом је владао Лудвиг Немачки, али и у Аквитинији на коју је претендовао Пипин II. Ово би значило да ће будући архиепископ Ремса, после Верденског споразума, морати да своје ингеренције прошири ван Западне Франачке и да политички балансира због опстанка црквене и манастирске имовине у својој архиепископији. Могло се десити да у тренуцима када је архиепископија упражњена неко од владара узме црквену земљу и подари је својим следбеницима на тим просторима. Ово ће условити три кључна проблема која су се наметала Хинкмару приликом управљања архиепископијом у Ремсу: статус неких клирика које је рукоположио архиепископ Ебо; уравнотежена политика, која би условила мир међу ривалским краљевима у подељеној Франачкој; и управљање и очување црквене имовине у својој архиепископији. ${ }^{12}$

Пошто су се Карлови наследници борили за престо централизоване империје што је раније укратко описано, Хилдуин се ставио на страну Лотара I, па је Хинкмар преживео његову судбину приликом прогона у Корви, у Саксонију. И поред прогонства, Хинкмар је остао у контакту са Лудвигом Побожним, те је после прогонства, уз Лудвигово одобрење, заједно са својим духовником враћен у манастир Светог Дионисија, где су заједно радили на обнови монашког живота, што потврђују Флодоард и сам Хинкмар у свом писму папи Николи (867), ${ }^{13}$ али повеља цара у којој потврђује повластице овом манастиру не помиње поименце Хинкмара. ${ }^{14}$

10 Flodoard 1854, 191, 256.

11 Sot $1993,20-40$.

12 Stone 2015, 6.

13 Epistola 198, 1990, 210: Conversis autem ad regularem vitam et habitum fratribus in monasterio sancti Dionysii, ubi nutritus fueram, in illud saeculum fugiens sine spe vel appetitu episcopatus aut alicuius praelationis diutius degui et exinde adsumptus familiaribus obsequiis praefati imperatoris ac episcoporum conventibus pro sola oboedientia mihi iniuncta inserviens post aliquot annos monasterii quietem repetii. Флодоард је у опису мало одређенији и каже да је Хинкмар помагао Хилдуину и цару како би се у манастиру обновили црквени и богослужбени живот. Flodoard 1854, 190.

14 Sot 1993, 490. 


\section{Хинкмар као архиепископ Ремса}

Стање у архиепископији у Ремсу било је врло турбулентно у периоду после Верденског споразума. Ове области су имале проблеме са Бретонцима, а повремено и са Викинзима. ${ }^{15}$ Поред спољних фактора, унутрашњи политички утицаји су условили да неколико пута дође до промене на катедри архиепископа у Ремсу, јер су на тај начин околни владари желели да утичу на верни народ и на саму црквену јерархију. Архиепископ ремски Ебо се - ипак - са катедре повукао тек 835. године, после сабора у Тионвилу, јер је прекршио заклетву на верност цару Лудвигу Побожном и приклонио се Лотару. Од 840. године Ебо се вратио на катедру, али се после четири године напокон повукао, jep je 844. године, папа Сергије II потврдио његово повлачење. У тим тренуцима, Хинкмар је играо врло важну улогу на сабору у Веру (844), а Карло га је после само четири месеца поставио за архиепископа. Његова позиција је потврђена на сабору у Бувеу у априлу 845. године. Хиротонисан је и постављен за архиепископа 3. маја исте године, док je две године касније (847) папа Лав IV послао Хинкмару палијум. ${ }^{16}$

Први задатак био је да поврати сву црквену имовину коју је архиепископија изгубила у деценији док је била - с времена на време - упражњена (835-845). Подвојеност у клиру у његовој епархији види се и из чињенице што га нису слушали свештеници које jе рукоположио Ебо, зато што је са њима дошао у сукоб јер је њихова рукоположења прогласио за неканонска. ${ }^{17}$ У том периоду папа потврђује манастиру Фулди привилегије, ${ }^{18}$ те потврђује права и привилегије која су дата заједно са палијумом Хинкмару (851), ${ }^{19}$ што наводи на закључак да се, половином 9. века, римски епископ интересује за дешавања у том делу Западне Европе. Папа се мешао и у односе Цркве и државе у франачким пределима 851. године, јер је Хинкмар из Ремса екскомуницирао једног Лотаровог великаша, који је имао наложницу, па се оженио по други пут, а своју прву жену је одвео у манастиру, на тај начин кршећи каноне, те је због тога морао да буде екскомунициран. ${ }^{20}$ Епископи су се жалили и на Хинкмарова јуридикциона права, па је однос на свим нивоима био поремећен и наредне године. ${ }^{21}$

15 Stone $2015,6$.

16 Regesta 1 1885, 2596 Hincmarum, archiepiscopum Remensem, donat "usu pallii et privilegio sedis apostolicae."

17 Stratmann 1991, 31.

18 Regesta 1 1885, 2605 Monasterii Salvatoris Fuldensis privilegia ac possessiones confirmat, petente Hattone abbate.

19 Regesta 1 1885, 2607 Lothario augusto postulanti, ut Hincmaro, Remensi archiepiscopo, „cotidianum sacri pallii usum et auctoritatem potestatemque praeoipuam, vice apostolica alios archiepiscopos vel episcopos sive abbates ipsius regionis per sacras canonum sanctiones iudicandi, licentiam daret", respondet, se Hincmaro pallii usum secundum exemplar, quod Lothario direxerit, libenter concedere, ut eo cotidie sacro fungens utatur officio; vices autem suas illi non tribuere, quia Sergius II. papa „eius deprecatione compulsus Drogoni archiepiscopo Mettensi vicariatum concesserit et pontificale praeceptum constituerit, ut omnis Franciae, Galliae seu Germaniae archiepiscopos, episcopos, abbates salvo in omnibus honore et gloria sanctae Romanae ecclesiae canonice Drogo iudi- caret" (Cf. supra reg. 2586).

2608 Hincmaro, Remensi arcliiepiscopo, cui pallium certis festivitatibus, ut praefatur, iam dederat (cf. supra reg. 2596), concedit pallium cotidianis usibus i.e "in diebus festis sive in consecratione episcoporum aut alio quocumque tempore", „beneficium, quod ab ipso pontificatus sui exordio usquequaque nulli archiepiscoporum ut ei simile concesserit, nec concedere deinceps quoquo modo suspicetur."

20 Regesta 1 1885, 2614 Hincmaro, archiepiscopo Remensi, opprobrat, quod Falcaricum (imperialem) vasallum excommunicaverit. Qui cum litteris Lotharii imperatoris et Ludovici regis fratris eius, veniens, professus sit, se concubina in coenobium dimissa aliam duxisse uxorem et hac ex causa absque omni canonico sive mundano iudicio excommunicatum esse. Angustias eius contemplans se dolere de excommunicatione scribit papa. Indulgentiam venialera erga cunctos commendat. Ut vasallo parcat et ecclesiae iterum societ iubet. Minis utitur, si de cetero excedat.

21 Regesta 1 1885, 2618 Omnibus episcopis Galliarum scribit opprobria contra Hincmarum, qui votum capessendi regulam. S. Benedicti solvisset, vivente Ebone archiepiscopo cathedram Remensem usurpasset 
Како би решио канонски проблем у јерархији, Хинкмар је сазвао сабор у Сасону 853. године те је саборски одлучено да су Ебова рукоположења ништавна, ${ }^{22}$ што је - уз Хинкмаров примат - потврдио и 855. године папа Бенедикт III. ${ }^{23}$ Овај проблем са почетка његове архиепископске каријере био је и остао камен спотицања између Хинкмара и нижег клира у Западној Франачкој током друге половине 9. века. ${ }^{24}$

Упоредо са тим, Хинкмар се суочио са још једним, можда и озбиљнијим, проблемом. Монах Готшалк дошао је у архиепископију Ремса док је она била упражњена и тадашњи хорепископ га је рукоположио за свештеномонаха. Почетком четврте деценије 9. века замонашен у Орбију, у Сасонској епархији, па је отишао у Ремс. Када је показао своје јеретичке склоности Храбанус, архиепископ Мајнца, упућивао је да Хинкмар реши проблем са Готшалком, јер је он био у надлежности архиепископа у Ремсу. Тако Готшалк долази у Ремс 848. године, исповеда своју веру у предестинацију пред Хинкмаром и овај, као одговорни архиепископ, промишља и бори се са јеретичким учењем скоро дванаест година, а доказ за то јесте и писање три списа против Готшалковог учења: Ad reclusos et simplices in Remensi parrochia contra Gothescalcum (850), један изгубљен спис (856) и De praedestinatione Dei (859-60). ${ }^{25}$ У решавању овог богословског проблема Хинкмару је одмагала ситуација са претходним архиепископом, јер су Ебоови пријатељи и сродници били против методологије његовог опонирања Готшалку, што је у ствари било усмерено против Хинкмарове архиепископске службе у Ремсу. Са друге стране, архиепископ Трира је наводио историјске аргументе како би своју јурисдикцију проширио на Ремс. ${ }^{26}$ Дакле, Хинкмар је имао и унутражње и спољашње проблеме током архиепископске службе у Ремсу.

У истом периоду, Хинкмар је био усредсређен да обезбеди православно исповедање вере у својој архиепископији, али је радио и на организацији (написао је два типика за своју архиепископију) и унапређењу духовности (наиме, 852. године обновио је Цркву Светог Ремигија и пренео његове свете мошти у ову светињу; можда је тада започео и писање Vita Remigii). ${ }^{27}$

Хинкмар је у првој деценији своје управе архиепископијом био у сталној вези са Карлом, а од 856. године један је од значајнијих саветника овог владара. Чак је сачинио

et nunc superbiae tumore infiatus imperatorem (Lotharium), a Paschali (I.) papa consecratum more solito una cura fratre Carolo rege et uxore ac filiis, anathemate iniuriasset. Lothario augusto eadem opprobria in Hincmarum ut supra reg. 2618 scribit. Addit, se mandare, ne Hincmarus eontra eum ,clam vel publice audeat aliquam quocumque tempore anathematis vel aliam iniuriae inferre iacturam."

22 Regesta 1 1885, 2631 Hincmaro, archiepiseopo Remensi, scribit, de confirmanda synodo Suessionensi ideo se haesitare, quod necdum acta sibi reddita sint, neque legati sedis apostolicae synodo interfuerint, neque ,imperialis epistola" allata sit, ,quae hoc, quod expetendum Hincmarus miserit, specialiter indieare potuisset", quod deniquo ii, quibus synodus dignitates abrogasset, sedem apostolicam appellaverint. 2632 Hincmaro, Remensi archiepiscopo, praecipit, ut congregata synodo sacerdotum, qui absque iusto ventilationis examine (in synodo Suessionensi 853 Apr. 23.) depositi sedem apostolicam expetierint, iterum sententia traetetur, et si quod minime se sperare ait, "noluissent obedire vel obtemperare iudicio eius, eis ad sedem apostolicam veniendi nullius possit hominis impedimentum nocere."

23 Regesta 1 1885, 2664. Petente Hincmaro, archiepiscopo Remensi, acta synodi Suessionensis II. (853) approbat, bac addita conditione: "Si ita est, nostro ut scriptis praesulatui intimasti et gestorum serie demonstrasti." Hincmari primatum confirrmat, sancitque, "ne quilibet dioeceseos Remensis eo contempto impune audeat, seu valeat aliena expetere iudicia, salvo in oranibus iure apostolicae sedis."

24 Stratmann 1991, 22.

25 Devisse 1976, 214-219.

26 Теудгауд из Трира вероватно 852. године започиње диспут са Хинкмаром око јурисдикције над Ремсом, јер је Трир био главни град римске провинције Belgica prima којој је био подчињен Ремс, главни град, области Belgica secunda. Види Schneider 2010, 85-91.

27 Stone 2015, 8-9. 
церемонијал за венчање Карлове ћерке, Јудите са краљом Есекса, Етелвулфом. ${ }^{28}$ Међутим, Хинкмарова улога је неповољно утицала на многе црквене великодостојнике, па је био изложен разним интригама и клеветама, које је успешно пребродио што због свог статуса на двору, што због своје архиепископске службе.

У Нормандији 858. године, Карло и Лудвиг су имали велике проблеме са Викинзима, али је Хинкмар био против Лудвигових акција. Овај владар је сазвао, у новембру исте године, сабор у Ремсу и позвао епископе Западних Франака, али су се они ипак сабрали у месту Керзи, на реци Оаза. ${ }^{29}$ То је иницирало једно подуже Хинкмарово писмо Лудвигу у коме је објаснио владару да епископи припадају његовој јурисдикцији, тако да га је молио да не нарушава предањски канонски поредак; а нагласак је био на томе да ће Божија казна стићи свакога ко буде напао помазаног владара, односно Карла. У том политичком контексту, Лудвиг се у јануару 859. године повлачи, а Карло обнавља своје територије којима влада у оквирима Верденског споразума. ${ }^{30}$ Ови догађаји су издигли Хинкмара као кредибилну личност која ће се бавити и дипломатским активностима у преговорима Карла, Лудвига и Лотара II. ${ }^{31}$ Хинкмарова улога била је да буде миротворац.

Већ је поменут однос са папом Николом (858-67), али би о односу франачких и епископа Рима требало истражити још чињеница. Ипак, остало је сведочанство да је папа Никола I потврдио привилегије манастиру Фулди и потврдио Теотона за игумана, као и његови претходници на римској катедри. ${ }^{32}$ Период од 861. до 882. године описује сам Хинкмар у историјском извору Annales Bertiniani, тако да је у тих двадесетак година описана политика франачких владара, црквени живот у Франачкој држави, али и однос Франака са папом. ${ }^{33}$

Папа Никола I био је један од најважнијих римских епископа у раном средњем веку, што због истицања папског ауторитета у свим споровима које је водио са црквеном јерархијом и на Западу и на Истоку, што због свог самосталног политичког статуса који је био пољуљан када је 864. године, Лудвиг II војно преузео управу над Римом. Хинкмар је описао како су Карлови посланици, као ходочасници, послати у Рим, али их је он пресрео и осујетио било какву везу са папом. ${ }^{34}$ Од тог догађаја, папска улога и његов ауторитет некако су усмерени на црквено-канонске проблеме, ${ }^{35}$ па је папа више расправљао о моралним, брачним проблемима, посебно у контексту владарских бракова

28 Devisse 1976, 354-60; Ordines coronationis Franciae 1995-2000, 73-123.

29 Devisse 1976, 313-27.

30 Goldberg 2006, 250-8.

31 Преговори између владара врхунили су се у састанку у Кобленцу (860). Затим је Хинкмар био саветник услед догађаја проузроковани браком Лотара II и Теутберге, која је била оптужена за инцестоидни однос са братом Хубертом. Она је после тешког периода исповедила неприродни однос са Хубертом и затражила од сабора да јој епископи одреде манастир у коме ће кајати своје грехе. Heidecker 2010; On the Divorce of King Lothar and Queen Theutberga 2016, посебно одељци Christian marriage and Frankish society и Theutberga's offences. После овог проблема - развод брака једног владара, Хинкмар је био умољен и да посредује у решењу проблема у браку Стефана и Енгелтруде. У овај случај се уплео и папа Никола I, па је Хинкмар био приморан да опонира самом папи. Stone 2015, 10; Regesta 1 1885, 2684. Hincmaro, archiepiscopo Remensi, et omnibus archiepiseopis et episcopis in regno Caroli (Calvi) regis constitutis, praecipit, ut, quae maritum Bosonem comitem deseruerit, Ingiltrudem, nisi revertatur, excommunicent.

32 Regesta 1 1885, 2676. Monasterii Salvatoris Fuldensis privilegia confirmat, petente Theotone abbate.

33 Nelson 1990, 35-40.

34 Davis 1995, 214.

35 Regesta 1 1885, 2716. Ecelesiae Bellovacensi concessa a Carolo (Calvo) rege monasteria duo, petente Odone episcopo, confirmat. 
и њихових наследника, а да је то радио и раније сведочи и пример Балдуиновог и Јудитиног брака. ${ }^{36}$ Папа Никола I се трудио да прошири ауторитет на вишу црквену јерархију на Западу, па је судио и извесним епископима, чак и када није добијао непосредне позиве да пресуди у неком случају - на добру комуникацију са франачким епископима указује параграф за 863. годину из Regesta. ${ }^{37}$ Папа је истакао своје искључиво право да потврди одлуке са сабора у Франачкој и другим западноевропским областима. Зато су се Хинкмар и папа Никола І сукобљавали по питању ограничења права папе, али само по неким питањима. ${ }^{38}$ Ипак је 863 . године, папа поновио правило: de monasteriuм custodia oductum et cuidam episcopo commondatum esse. ${ }^{39}$ Тако је папа на страни епископа, у овом случају Хинкмара у Ремсу, по питању послушања игумана из манастира у областима где је јурисдикционо право у рукама архиепископа у Ремсу. То је било потребно да се нагласи зато што су понекад политичке ингеренције владара и великаша биле изнад канонских права једног епископа у својој епархији.

Тада су покренута и нека питања из канонског права која до тада нису била расправљана: Хинкмар је оспоравао ауторитет папских декрета, односно писама која указују на папску одлуку по неком питању, а која се косила са саборским канонима. Папа Никола је узео себи за право да исправља или - на свој начин - тумачи чак и каноне Васељенских сабора, што је Хинкмар недвосмислено оспоравао и говорио да папске одлуке имају мањи ауторитет од саборских канона, поредећи папске декрете са старозаветним Законом у односу на - претежније - јеванђељско учење. Франачки епископи су тражили да и они символишу апостоле, у контексту давања ауторитета римском папи од стране апостола Петра, те су на тај начин желели да се отргну од папе и нису хтели да беспоговорно буду послушни епископу у Риму. Хинкмар је - може се рећи - био један од највећих заговорника другачије еклисиологије у односу на папску. Овде су се разликовала два концепта саборности и поимања Цркве: римски је био усмерен на папску монархију, а франачки на самосталност и црквени ауторитет архиепископа̂ и митрополитаิ, али са изразитим саборним утицајем приликом решавања многих црквених питања, а посебно приликом решавања питања односа Цркве и државе. Са друге стране, Хинкмар је двоструко посматрао спољну и унутрашњу црквену политику - можда несвесно, а можда и не - он је опонирао папи Николи апсолутну црквену власт и

36 Папино интересовање за породичне односе франачких владара види се из његовог писма Хинкмару 864. године. У писмо папа расправља о случају епархије камбријске, затим о браку између Балдуина и Јудит, па о свргавању Ротада са епархијске катедре и на крају, о јереси Готшалка, што указује на велики догматски проблем са којим се Хинкмар борио више деценија на шта указује папа. Ипак је у писму папа подржао Хинкмара по питању камбријске епархије, односно порицао је Лотаров избор Хилдуина. Вероватно је већ 866. године пронађена алтернатива Хинкмару и изабран је други архиепископ за Ремс. Hincmar, Epistola 169, MGH Epp. 8, 144-63; Genke V. and Gumerlock 2010, 175. У вези са тим и са свргавањем Ротада, архиепископ није имао подршку свих својих суфрагана. Види Regesta 1 1885, 2712. Hincmaro, archiepiscopo Remensi, praecipit, a sacris abstineat, nisi intra dies 30 Rothadum, episcopus Suessionensem, ab exsilio revocatum in pristinumque restitutum, cum calumniatoribus eius Romam miserit. Да би Ротадов епископски статус обновио 865. године: Hincmaro, archiepiscopo Remensi, Rothadum, episcopum Suessionensem, restitutum nunciat. Regesta 1 1885, 2784.

37 Regesta 1 1885, 2749: Hincmaro Remensi et Waniloni Rotomagensi ceterisque archiepiscopis et episcopis, in regno Caroli (Calvi) regis constitutis, earundem litterarum exempla mittit.

38 Scholz 2006, 191. О браку Балдуина и Јудит папа је рекао (863): Hincmaro, archiepiscopo Remensi, sub excommunicationis poena praecipit, ut Iudith, Caroli (Calvi) regis filiam, "paternis ae maternis obtutibus praesentandam suscipiat, si tamen intelligat, quod confestim rex, quae do illa sibi scriptis et verbis per legatos (Rhadoaldum et Iohannem) spopondit, adimplere velit; quodsi, eorum animos ad id protelandum esse intentos, investigare possit, nequaquam eam recipiat," те је ипак стао на Хинкмарову страну.

39 Regesta 1 1885, 2737. 
ауторитет, а наметао је исто то суфраганима и епископима у својој области јурисдикције. ${ }^{40}$ Папа је редовно слао своје легате да успоставе папски ауторитет у свим областима Западне Европе, међутим, они су били онемогућени да изврше папске одлуке како на просторима Хинкмарове јурисдикције, тако и на осталим франачким територијама.

Хинкмар и епископи су 866. године помазали Карлову краљицу, Ерментруду како би родила здраве синове наследнике. ${ }^{41}$ Карло је желео да се повеже са Римом, па је 867. године после сабора у Троу одлучено да се ни један епископ у Франачкој држави не хиротонише без саветовања са римским понтифом и његове коначне одлуке. ${ }^{42}$ После тог сабора, у писму епископа папи, које је вероватно писао сам Хинкмар, тражен је палијум за архиепископа црквених области под Карлом, а у том тренутку - архиепископ Карлових области јесте Вулфад. Био је то још један од доказа владарске политике франачких краљева после Карла Великог: да контролишу епископе, велику црквену имовину и унутрашње црквене ствари. ${ }^{43}$

Крајем седме деценије 9. века, Хинкмар је поново потврдио своја архиепископска права над својим суфраганима, да би на крају запао у сукоб са својим нећаком, лаонским епископом Хинкмаром. Архиепископ Хинкмар је у почетку подржавао свог нећака када је, у јулу 868, Карло позвао епископа лаонског да одговори на оптужбе за тамничење људи у његовој епархији. Хинкмар из Ремса је - тада - написао неколико расправа, залажући се за одбрану црквене имовине и устао је против идеје да се клирику може судити пред световним судом. ${ }^{44}$ До лета 869 . године, међутим, Хинкмар Лаонски се залагао за озбиљна ограничења архиепископске власти у односу на суфрагане и оближње епископе. ${ }^{45}$

Међутим, ову борбу за црквену јурисдикцију и црквена права у држави засениле су политичке околности: половином августа 869. године краљ Лотар II умро је у Италији, а Лудвиг Немачки је био тешко болестан. Карло је искористио ту прилику и преузео Лотарингију. У Мецу га је крунисао Хинкмар, архиепископ Ремса. Карлова супруга Ерментруда је умрла у октобру, а после само шест дана Карло је запросио Рихилду, сестру Босоа, истакнутог лотариншког војводе. ${ }^{46}$ Међутим, овоме се успротивио Хинкмар, па је Рихилду називао Карловом конкубином. Лудвиг Немачки се у томе опоравља од болести и прети ратом Карлу, ако не напусти Лотарингију. Карлов син, Карломан се, такође, надао да ће осигурати контролу над делом Лотарингије, вероватно желећи да обезбеди свој статус - пре него што се из новог брака роде полубраћа. Лудвиг и Карло су 870. године поделили Лотарингију између себе; а сабор је Карломана лишио права на територије, те су приморали Хинкмара из Лаона да положи заклетву лојалности Карлу и Хинкмару из Ремса. ${ }^{47}$

Ти догађаји су наизглед смирили ситуацију и у Цркви и у Франачкој држави. Међутим, Карломан је наставио да се бори за своју територију, па је утамничен, ослепљен, а затим је коначно кажњен у чему је и Хинкмар из Ремса учествовао тако што је потврдио

40 Tavard 1973, 594-623

41 Coronatio Hermintrudis reginae 866, 453-5.

42 Council of Troyes (867) - MGH Conc. IV, no. 24 A, 237: ... futuris temporibus praeter consultum Romani pontificis de gradu suo quilibet episcoporum deiciatur.

43 PL 125, cols 1036-66.

44 PL 125, cols 1035-70.

45 Die Streitschriften Hinkmars von Reims und Hinkmars von Laon 2003, 1-2.

46 Nelson 1988, 110-115.

47 MGH Conc. IV, no. 33, 380-95. 
Карломанову казну са догматске стране користећи списе бл. Августина. ${ }^{48}$ Затим је 871. године, Хинкмар из Лаона свргнут са катедре, утамничен и после две године ослепљен. У овој ситуацији се франачки владар, Карло обраћа папи Адријану II (867-872) за савет, а надасве за потврду стања у Цркви и држави и наравно, за могућност коришћења црквене имовине. Међутим, папа је имао врло мали утицај на франачке интересе, што се види и из неуспелог Хинкмаровог покушаја да премести епископа Актарда из Нанта у Тур. ${ }^{49}$ Све ове околности условиле су извесно смањење Хинкмаровог утицаја у Франачкој држави, па је од 873. године, он мање значајан за Карла, као владара, од млађих епископа и игумана. Лудвиг II и Карло су се суочили због територије Италије, док је Лудвиг Немачки заузео Западну Франачку. ${ }^{50}$

Карла је папа Јован VIII (872-882) у Риму на Божић 875. крунисао за цара, па се он као цар вратио у Западну Франачку, те се Лудвиг повукао. На Карла је утицао његов нови статус у држави: одржао је сабор у Понтиону у јуну 876. године, током кога су његови великаши положили заклетву послушности. Хинкмар се успротивио формулисању заклетве, желећи да епископска заклетва на верност буде право само вишег клира, али се његов глас није чуо на двору. ${ }^{51}$ Његов став произашао је из бриге да нагласи узајамну одговорност краља и епископа. Тако је Хинкмар губио своју позицију у - сада измењеним - друштвеним околностима. Највећи ударац је био онај из 877. године, када је Карло избацио Хинкмара из друштва поверљивих у борби против Лудвига.

На несрећу Хинкмара, Карлови наследници су наставили очевим путем и нису га звали да их саветује. Иако је Хинкмар одиграо важну улогу приликом Лудвиговог крунисања у децембру 877. године, он је позвао друге саветнике, док њега није звао. Када се Лудвиг тешко разболео у лето 878. године и умро у априлу следеће године, Хинкмар није био одређен за старатеља његових синова, Лудвига III и Карломана. ${ }^{52}$ Иако је Хинкмар изгубио статус у дипломатским мисијама франачких владара које је имао до 878. године, још увек је имао идеју да саветује младе краљеве и да обезбеди да се Црквом правилно управља.

Писмо које је Лудвигу Хинкмар послао са сабора у Фиму (април 881) може да буде његов политички тестамент, јер се у њему резимирају Хинкмарове идеје о односима две силе, државне и црквене власти, и наглашава разлика у менталитету и мислима мудрих, старих саветника, као што је на пример био Хинкмар, и младог владара. ${ }^{53}$

Хинкмар ни у старости - међутим - није изгубио борбеност, елан, нити ентузијазам за писањем. Треба нагласити два текста писана 882. године, јер резимирају све његове идеје и животне преокупације. Чак и Хинкмаров агиолошки текст Vita Remigii, сумира његове погледе на богословље и црквени поредак, јер говори о епископу као законодавцу. Други текст је уједно и Хинкмарово последње дело, De ordine palatii ${ }^{54}$ написано у јесен 882. године, за Карломана II који је тада требало да ступи на царски престо, након што је његов брат Лудвиг III умро, па је Карломан наследио читаву Западну Франачку. Хинкмар овде представља визију идеалног суда (са истакнутом улогом свештеника на двору) и тврди да је о тим стварима сазнао од Адаларда, који је исто дело,

48 PL 125, cols 833-56.

49 Sommar 2002, 429-45.

50 Nelson 1992, 239-43.

51 Odegaard 1945, 285.

52 Devisse 1976, 966-76.

53 Council of Fismes, 881, MGH Conc. V, no. 15, 166-200. О односу Хинкмара и Лудвига III види у Devisse 1976, 980-95.

54 Hincmar 1980, 42. 
чак и са истим насловом, написао пре шездесет година у тренутку крунисања Карла за цара. Хинкмар је овде свесно направио везу са ранијим, бољим временима, а уједно цитира Карла Великог и Лудвига Побожног. ${ }^{55}$ У нападу Викинга на Ремс, војни контигент овог града помагао је Карломановој војсци, па је Хинкмар морао да побегне из града ноћу, узимајући са собом два витална ресурса: свете мошти Ремигија и благо цркве у Ремсу. Иако је Хинкмар пред крај свог живота био толико слаб да га је требало носити на преносној столици, он је писао до тренутка своје смрти у децембру 882 . године. ${ }^{56}$

Иако је било проблема, током тридесет година колико је као архиепископ Ремса провео у улози веома важног црквеног великодостојника и утицајног човека, Хинкмар је био инспиратор многих реформи и допринео је томе да владари одобре многе повластице Цркве. Као познавалац дворског церемонијала и одлучни борац за црквене интересе у великој држави, Хинкмар је активно учествовао у великим политичким и црквеним догађајима свог времена, а био је ревносан у остваривању најширих црквених привилегија и митрополитанских права Цркве у Ремсу. У својој борби био је приморан да добро изучи црквено-канонско право како би могао да предањски и црквеним језиком одговори на све захтеве тадашње владајуће елите. Са друге стране може да се истакне да је током 9. века утицао на начин владавине у краљевству Западне Франачке.

\section{Закључак}

Када је средином 10. века, Флодоард, каноник Саборне цркве у Ремсу, сакупљао грађу да напише историју Цркве у Ремсу, дошао је до закључка да ће живот и деловање Хинмара из Ремса бити основ за ту историју, те да ће он бити средишња фигура, јер је био архиепископ у Ремсу у великом делу друге половине 9. века, између 845 . и 882 . године. Приликом писања Флодоард је имао велику помоћ пошто су сва Хинкмарова писма била сачувана, па је заједно са свим његовим списима, управо на тој грађи и базирао Historia Remensis ecclesiae. Хинкмаров живот трајао је упоредо са развојем каролиншке империје, са свим успонима и падовима после Карлове смрти, па све до Карла Дебелог. Његов дуг земаљски живот ишао је упоредо са постојањем Франачке државе. Не само да је био сведок догађаја у 9. веку у Каролиншкој држави, већ је као црквени великодостојник био и једна од водећих фигура у политичком контексту, што доказује и његова волуминозна грађа и списи који су по садржају веома разноврсних тема̂: од теолошких, преко историјских, агиографских, моралних, канонских, литургичких, па све до писама̂ и политичких списа̂. Може се закључити да 9. век у Франачкој држави и Западној Европи може да се анализира и кроз синтезу живота и рада Хинкмара из Ремса.

55 R. McKitterick 2008, 24.

56 J. M. Wallace-Hadrill 1981, 48-65. 


\section{Литература}

\section{Извори}

Die Streitschriften Hinkmars von Reims und Hinkmars von Laon 869-871 (2003): MGH Conc. IV, Supplementum 2, Hanover.

Flodoard (1854): Historia Remensis ecclesiae, Reims.

Hincmar (1980): De ordine palatii, ed. T. Gross and R. Schieffer, MGH Fontes iuris 3, Hanover.

Hincmar (1990): Epistola 198, MGH Epp. 8, MGH Fontes iuris 7, Hanover.

Monumenta Germaniae Historica (301): Coronatio Hermintrudis reginae, 866, MGH Capit. II. 24.

Monumenta Germaniae Historica (24): Council of Troyes, 867, MGH Conc. IV, no.

Monumenta Germaniae Historica (15): MGH Conc. V, no. 15.

Monumenta Germaniae Historica (1992): MGH Conc. IV, Supplementum 1, Hanover. Monumenta Germaniae Historica (33): MGH Conc. IV, no. 33.

On the Divorce of King Lothar and Queen Theutberga (2016): On the Divorce of King Lothar and Queen Theutberga, by Hincmar of Rheims, trans. R. Stone and C. West, Manchester.

PL 125: Hincmar, De regis persona et regio ministerio ad Carolum Calvum regem, cols 833-56.

PL 125: Juramentum quod Hincmarus Archiepiscopus edere jussus est apud Pontigonem col. 1128

Regesta 1 (1885): Jaffé, Philipp, Regesta Pontificum Romanorum, Veit et Comp. Kohlhammer.

Zwei Schriften des Erzbischofs Hinkmar von Reims (1889): ed. W. Gundlach,

\section{Монографије и чланци}

Böhringer L. (1992): 'Einleitung', in Hincmar of Rheims, De Divortio Lotharii regis et Theutbergae reginae, ed. L. Böhringer, Hannoverae.

Devisse, J. (1976): Hincmar, archévêque de Reims, 845-882, I, II, Droz: Geneva.

Davis R. (1995): The Lives of the Ninth-century Popes (Liber pontificalis): the Ancient Biographies of Ten Popes from A.D. 817-891. Liverpool.

Genke V. and Gumerlock F. X. (2010): Gottschalk and a Medieval Predestination Controversy: Texts Translated from the Latin, Milwaukee.

Goldberg E. J. (2006): Struggle for Empire: Kingship and Conflict under Louis the German, 817-876, Ithaca.

Heidecker K. (2010): The Divorce of Lothar II: Christian Marriage and Political Power in the Carolingian World, trans. T. M. Guest, Ithaca. Cambridge.

McKitterick R. (2008): Charlemagne: the Formation of a European Identity,

Nelson J. L. (1988): "A tale of two princes: politics, text and ideology in a Carolingian annal", Studies in Medieval and Renaissance History, 10, 110-115.

Nelson J. L. (1990): 'The "Annals of St. Bertin"', in M. T. Gibson and J. L. Nelson, eds, Charles the Bald: Court and Kingdom, 2nd revd edn, Aldershot.

Nelson J. L. (1992): Charles the Bald, Routledge. 
Ordines coronationis Franciae (1995-2000): Texts and Ordines for the Coronation of Frankish and French Kings and Queens in the Middle Ages, 2 vols., R. A. Jackson, ed., Philadelphia.

Odegaard C. E. (1945): "The concept of royal power in Carolingian oaths of fidelity", Speculum, 20, 267-285.

Patzold S. (2008): Episcopus: Wissen über Bischöfe im Frankenreich des späten 8. bis frühen 10. Jahrhunderts, Ostfildern.

Schneider O. (2010): Erzbischof Hinkmar und die Folgen: der vierhundertjährige Weg historischer Erinnerungsbilder von Reims nach Trier, Berlin.

Schrörs, J. H. (1884): Hinkmar, Erzbischof von Reims: Sein Leben und seine Schriften, Freiburg im Breisgau.

Scholz S. (2006): Politik - Selbstverständnis - Selbstdarstellung. Die Päpste in karolingischer und ottonischer Zeit, Stuttgart.

Sot, M. (1993): Un historien et son Église au Xe siècle: Flodoard de Reims, Paris: Fayard.

Sommar M. E. (2002): "Hincmar of Reims and the canon law of episcopal translation", Catholic Historical Review, 88, 429-445.

Stratmann M. (1991), Hinkmar Von Reims als Verwalter von Bistum und Kirchenprovinz, Jan Thorbecke Verlag, Stuttgart.

Stone R. (2015): “Introduction: Hincmar's world”, Hincmar of Reims, Life and Work, eds. Rachel Stone, Charles West, Manchester University Press.

Tavard G. H. (1973): 'Episcopacy and apostolic succession according to Hincmar of Reims', Theological Studies, 34, 594-623.

Wallace-Hadrill J. M. (1981): "History in the mind of Archbishop Hincmar", in R. H. C. Davis and J. M. Wallace-Hadrill, eds, The Writing of History in the Middle Ages: Essays presented to Richard William Southern, Oxford. 


\section{Ivica Čairović}

\section{THE STATUS OF HINCMAR OF REIMS (806-882) ON THE COURT OF CHARLEMAGNES SUCCESSORS AND IN FRANKISH CHURCH. BIOGRAPHICAL SKETCHES AND THEOLOGICAL CONTRIBUTION}

The aim of the study is to reevaluate status of Hincmar of Reims in the Frankish Empire and in relationship between Achen and Rome. Hincmar's life is threefold analyzed. In the first place, the attitude of the successor of Carlo is great among themselves and with all relevant factors in the Western Europe, then the semicolons will be seen through the prism of the work of Hincmar, with a special reference to the Roman bishop and the development of Roman primacy in the West Europe in the Middle Ages. In addition to the historical events, Hincmar participated in Church life in Frankish Empire through the council's actions, writing, so that the human-canon analysis of Hincmar's action will read the spiritual situation on the Frankish court and in the villages and cities throughout Frankish State. The conclusion of this research should help to analyze the relationship between Rome and Frankish Empire, but also the development of the German mentality in the Christian Ethos of Western Europe in the Middle Ages.

Although there was a problem, during thirty years, in the life of Hincmar as the archbishop of Reims, he spent a very important Church generosity and an influential man. Hincmar was also an inspirer of many reforms and contributed to the rulers approve many church benefits. As a connoisseur of the court ceremony and a decisive fighter for Church interests, Hincmar actively participated in the great political and Church events of his time, and was in realizing the widest Church privileges and the Metropolitan rights of the Archbishoporic of Reims. In his struggle, Hincmar was forced to rule out Church and canonically so that he could respond to all the demands of the then ruling elite. On the other hand, it can be emphasized that Hincmar influenced the manner in the kingdom of Western Frankia during the 9th century. 